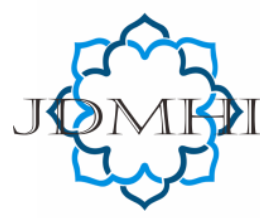

email: jdmhi@walisongo.ac.id

Journal of Digital Marketing and Halal Industry

ISSN: 2716-4810 (print) ISSN: 2716-4802 (online)

\title{
The Impact of Shopee's Youtube Ads Shopee Version 4.4 Mega Elektronik Sale on Purchase Intention
}

\section{Zuhdan Ady Fataron}

Universitas Islam Negeri Walisongo, Semarang, Indonesia

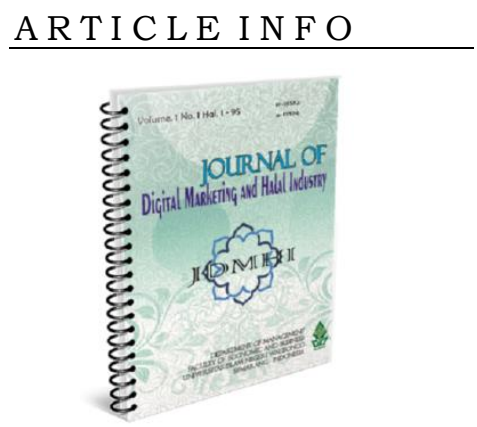

Article history:

Received 7 March 2021

Accepted 22 April 2021

Published 30 April 2021

Keywords:

Youtube Ads, Shopee Ads,

Buying Interest

\section{A B S T R A C T}

\begin{abstract}
Shopee's e-commerce in recent years has dominated the Indonesian online market because it offers a variety of attractive features. The support for Youtube Ads makes it easier for businesses to offer their products online. Shopee ads are packaged in Youtube Ads with a tagline that can spark consumer interest. One of the Shopee Ad taglines is Shopee 4.4 Mega Elektronik Sale. This tagline is quite booming considering that electronics is a part of modernization which is the basic need of generation Z. This study aims to measure how far the exposure of Shopee's 4.4 version of Shopee's advertisement is. Mega Elektronik Sale: New Refrigerator, Price Slams 50\% on student buying interest. The novelty in this study refers to Youtube's capacity as an advertising medium to influence student purchase intentions as the largest market share of electronic products. The research is structured with a quantitative approach with a survey method. The results showed that $44 \%$ of students' buying interest was influenced by the Shopee advertisement version of the Shopee 4.4 Mega Elektronik Sale. The Shopee ad version of Shopee 4.4 Mega Elektronik Sale has a positive and significant effect on buying interest with a fairly strong correlation value, namely 0.663 which indicates that the stronger the advertising intensity can directly increase student buying interest.
\end{abstract}

@2021 Journal of Digital Marketing and Halal Industry

\section{Introduction}

The survey of the Indonesian internet service providers association as of November 2020 stated that the number of internet users in Indonesia rose to $73.7 \%$ of the total population in the second quarter of 2020 (APJII, 2020). This number is equivalent to
196.7 million users of a total population of 271 million. This condition makes Indonesia one of the countries with a high potential for digital-based economic growth (Kamila \& Usman, 2021). Digital-based economic development can provide opportunities for business actors to develop their business potential. Businesses can take advantage of

\footnotetext{
* Corresponding author.email: zuhdan_ady_fataron@walisongo.ac.id
}

DOI: http://dx.doi.org/10.21580/jdmhi.2021.3.1.7442 
technological sophistication to present an online marketplace that can virtually meet consumers. E-commerce platforms mediate economic transactions with the concept of digitization. E-commerce is an electronic information service with internet support that can accommodate product sales and purchase activities (Layla \& Usman, 2019). Data research compiled by the German company Statista states that the total e-commerce revenue in Indonesia reached its highest value in 2020 amounting to U $\$ 27$ billion (Statista, 2020). E-commerce in Indonesia in 2017 only earned $U \$ 8$ billion and is projected to grow to $\mathrm{U} \$ 48$ billion by 2024 .

Based on the publication of joint research by Google and Temasek 2017, Indonesia is said to be a good market for the development of ecommerce because mobile internet users reach an average of 3.9 hours per person per day, and this number exceeds the Southeast Asian average of 3.6 hours per person per day (Oxford Business Group, 2020). This condition is exploited by various e-commerce developers to make Indonesia a potential market. The forms of e-commerce that are quite developed in Indonesia are very diverse, starting from Shopee, Tokopedia, Bukalapak, Lazada, BliBli, Bhineka, F-Things, and several other websites. As for the fourth quarter of 2020, Shopee ranks first among the most clicked e-commerce sites in Indonesia, followed by Tokopedia and Bukalapak (Statista, 2021b). Shopee is a Singaporean company that has successfully entered the ASEAN market. This Sea Group subsidiary can attract high engagement compared to its competitors (Taruli et al., 2020). Shopee's ecommerce is even able to force conventional retail business actors to adjust to the digitalization trend by promoting web sales or collaborating to become sellers on the platform (Daryanto et al., 2020). This is supported by the statement of Kamila $\&$ Usman (2021) which states that consumer interest in online shopping can attract business people to be more competitive in selling their products through e-commerce.

Oxford Business Group (2020) describes several online products that are quite in demand in Indonesia, such as fashion, electronics, and groceries with a total transaction of $U \$ 9.5$ billion, followed by online travel purchases worth U \$ 9.4 billion. Fashion, electronics, and groceries as attractors for online businesses have received high engagement on the Shopee platform. Taruli et al (2020) stated that Shopee is a platform that always presents innovation in its features to attract consumer interest to extend consumer access time (time spent) and customer engagement. Shopee has gotten enough engagement from the people of Indonesia, but Shopee's marketing and advertising are still quite intensively carried out even with other social media such as Facebook, Instagram, and Youtube.

Inkiriwang et al (2021) stated that Youtube is the third most popular site with the slogan "Broadcast Yourself". Youtube is even able to broadcast nearly 5 billion videos every day. Orinaldi (2021) stated that YouTube social media has the potential to be used as a product promotion forum. This is supported by the statement by Hansen et al (2014) which states that global social media has empowered consumers to share brand images widely through online videos. This condition encourages business people to take advantage of this media as a connector for digital 
product marketing. The slogan broadcast yourself increasingly triggers business people to show the advantages of products that are attractively packaged through online videos. Youtube has become a medium for video ads with a budget below television advertising operations, thereby eliminating the stigma that advertising can only be done by companies with large budgets.

Youtube began to load advertising content from a variety of products to make it more attractive to consumers to buy. This is also used by Shopee as a platform that is quite consistent in promoting on youtube media. Shopee even received an award because it was included in the top ten Most Popular Video Ads in the Indonesian Youtube version in 2017 with the tagline "Shopee Godaan" (Warta Ekonomi, 2018). Shopee ads are back in the ranks of the most popular ads on Youtube in the January 2020 - June 2020 period with the tagline "Shopee Big Ramadhan Sale" (Kompas, 2020). In 2020 Shopee also had an attractive offer through the tagline "Shopee 4.4 Mega Elektronik Sale" which was campaigned to meet the needs of hunters for the latest electronic products. This was initiated from an increase in demand for electronic products since "Sale 12.12" in 2018 and "Sale 12.12" in 2019. Electronics are part of the lifestyle for some young people in modern times, so Youtube ads that offer promos related to electronic products are marketed through The Shopee platform has the potential to get quite high engagement. The higher the consumer's engagement with a product, the greater the potential to attract consumers to buy the product.

The urgency of research related to the impact of Youtube ads with Shopee's e-commerce promo content on the interest in buying electronic products is related to the closer the younger generation is to technological sophistication. The results of the BPS census (2020) show that the highest contributor to the population figure comes from Generation $\mathrm{Z}$ who was born in the period 1997 - 2012. As for the social development of students, they are in the early adulthood stage with an age range of $18-25$ years (Hayani \& Wulandari, 2017). This age range is included in the Gen $Z$ category which in this case is also referred to as i-Generation or internet generation. Hadion Wijoyo et al (2020) stated that generation Z has the characteristics of being tech-savvy, dependent on the social environment, expressive, multitasking, fast switcher, and happy to share. Studies on US use of Youtube also prove that $77 \%$ of US internet users aged 15 to 25 years are the biggest users of Youtube in 2020 (Statista, 2021). Therefore, the intensity of Youtube advertisements that broadcast electronic product promos can influence the interest in buying Generation $\mathrm{Z}$ because these ads are a driving force for the emergence of interest from within individuals.

This research is in line with the research of Arnianti et al (2019) that YouTube advertising positively and significantly affects students' interest in buying Vivo Smartphone electronic products. The research survey activity by Orinaldi (2021) also proves that the exposure of Shopee advertisements on the Youtube page has a positive and significant effect on purchasing an interest in the public. Duffett et al (2020) also emphasized in their research that a Youtube advertising strategy can stimulate interest in buying products. Online social communication through Youtube social media will automatically attract customers to find information about promotional products. 
Research Dyego \& Oktavianti (2020) also reiterates that the clarity of advertising communication can influence consumer interest in buying products. This study aims to determine how much influence Shopee Youtube Ads Shopee Version 4.4 Mega Elektronik Sale: New Refrigerator Price 50\% lower on the buying interest. Ease of access to ad content can lead to positive or negative responses that trigger involvement in spending (Rubiati \& Heriyana, 2020).

\section{Literature Review}

\section{Marketing Strategy Through Advertising}

Advertising is part of a marketing technique that buys time and space so that promotional messages can be conveyed (Morisaan, 2010: 17). Advertising activities tend to contain a narrower concept when compared to marketing activities. Inkiriwang et al (2021) defines advertising as a form of conveying information from a person, agent, institution, or company whose content persuades the public to be interested in the products offered. Advertising is also defined as presenting products in the form of media messages to be conveyed to the public (Layla \& Usman, 2019). Dewi \& Hartono (2019) state that advertising is a form of non-personal communication carried out to promote products. The effectiveness of advertising in product promotion is very dependent on the concept of promotion following the targeted market segmentation. Advertising is the presentation of non-personal information related to products, trademarks, and companies that are run with certain compensation (Inkiriwang et al., 2021). Advertisements are generally displayed through media that are easily accessible to the general public, both online and offline.

Advertisements are required to provide detailed information and attractive promotional visuals to gain more engagement and trust from consumers (Kamila \& Usman, 2021). Meanwhile, Morisan (2010: 18) states that the advantages of advertising as a promotional medium are due to 1) cost efficiency with more audience affordability, 2) creating a brand image and symbolic form of the company, and 3) attracting consumers through the popularity of advertising. The purpose of advertising in general is to convey product information so that consumers know and use the products offered. However, each company has a nature, character, approach, and advertising strategy that varies according to the situation and needs. Layla \& Usman (2019) states that the quality of advertising can also be measured by indicators of attention, interest, trust, and action.

The key aspect in advertising lies in the success of persuasion which is influenced by the components of suggestion, delivery of messages, personal influence, and source credibility. Suhandang (2016: 114) states that the advertising strategy that creates persuasion success can be done with the A to A procedure or from attention to the action method, which describes the process of raising attention with an effort to move the audience to act as suggested (persuasion). The concept of A- to A procedure can be described with a more complete concept in the form of attention (attention), interest (interest), desire (desire), decision (attention), and action (action) or can be abbreviated as AIDDA (Wijaya \& Siahaan, 2020). This concept can also be explained in terms of AIDMA with five basic stages: 
attention, interest, desire, memory, and action. (Hu \& Qiao, 2018) states that globalization and internet development have renewed the concept of modern marketing into AISAS with stages in the form of attention, interest, search, action, and sharing.

\section{Purchase Interests}

Wijaya \& Siahaan (2020) defines interest as a desire and curiosity that arises from within oneself. Interest is the second stage that is passed in the advertising strategy after the communicator has succeeded in cultivating attention. Interest is also a factor that comes from within the individual which shows a tendency towards something in the heart. Thus, buying interest is a purchase planning process caused by consideration of product needs, branding, and consumer behavior (Layla \& Usman, 2019). Meanwhile, Inkiriwang et al (2021) argue that consumer purchase interest is a mental statement of consumers related to planning to purchase certain products. Therefore, buying interest can be reflected in the consumer's intention which describes his desire for the quality and quantity of a product.

Interests can be influenced by various factors including stimuli and objects (Wijaya \& Siahaan, 2020). The stimulus can influence consumer perceptions to be more interested in the products offered. Foster \& Johansyah (2019) also emphasize that buying interest is obtained from the learning and thinking process so that it can shape consumer perceptions. Purchase interest can motivate consumers so that they can form a strong desire that must be actualized properly. Consumers' knowledge of product quality also contributes to increasing consumer buying interest. This is what makes detailed, accurate, and transparent information required to be submitted by producers or sellers to attract consumers in making purchasing decisions. Inkiriwang et al (2021) also stated that buying interest is part of a series of alternative evaluation processes before the buyer determines the product chosen. The interest in buying a product can be determined by indicators in the form of transactional interest, referential interest, preferential interest, and exploration interest (Layla \& Usman, 2019).

\section{The Method, data, and analysis}

This research was conducted using a quantitative approach. The research implementation aims to explain facts, cause and effect relationships, predict, emphasize facts and predictions (Manzilati, 2017). Researchers used quantitative research methods using survey methods. The sampling technique used by researchers in this study is purposive sampling. The sample in the study was calculated using the Slovin formula. Based on the calculation, the sample size was 44 students. The research data is in the form of primary data and secondary data. Primary data were collected using a questionnaire instrument. Secondary data is obtained or collected by researchers from various existing sources, either from official bodies or institutions, books, reports, journals, and other scientific studies. Teknik Analisis Data menggunakan uji korelasi dan regresi.

Correlation test formula using;

$$
r=\frac{n(\Sigma X Y)-(\Sigma X \cdot \Sigma Y)}{\sqrt{[n \Sigma 2-(\Sigma) 2 X X] / n \Sigma 2-(Y \Sigma) 2 Y]}}
$$

Information: $\mathrm{r}$ : Correlation coefficient $\mathrm{n}$ : Number of respondents $\mathrm{x}$ : Variable score (respondent's answer) y: Total score of the variable (respondent's answer). 
The regression test formula uses;

$$
\begin{gathered}
\mathrm{Y}=\mathrm{a}+\mathrm{bX} \\
\mathrm{a}=\frac{(\Sigma y)(\Sigma 2 X)-(\Sigma X)(\Sigma X Y)}{n(\Sigma 2 \mathrm{x})-(\Sigma) 2} \\
\mathrm{~b}=\frac{\mathrm{n}(\Sigma \mathbf{x y})-(\Sigma \mathbf{x})(\Sigma \mathbf{y})}{\mathrm{n}(\Sigma 2 \mathrm{x})-(\Sigma) 2}
\end{gathered}
$$

Information: $\mathrm{Y}$ ': The dependent variable (predicted value) $\mathrm{X}$ : Independent variable a: Constant ( $\mathrm{Y}$ value if $\mathrm{X}$ $=0$ ) $\mathrm{b}$ : Regression coefficient (value of increase or decrease)

\section{Result and Discussion}

\section{Characteristics of Respondents}

In this study, researchers used 45 respondents as the sample population, namely students and female students. Based on the data obtained through a questionnaire, there are the following results;

Table 1. Mapping results based on gender

\begin{tabular}{ccc}
\hline Gender & Frequency & Percentage \\
\hline Man & 11 & $24 \%$ \\
Women & 34 & $76 \%$ \\
Total & 45 & $100 \%$ \\
\hline
\end{tabular}

Table 2. Mapping Results by Age

\begin{tabular}{ccc}
\hline Age & Frequency & Percentage \\
\hline $19-24$ Years & 30 & $67 \%$ \\
$25-30$ Years & 12 & $27 \%$ \\
$31-35$ Years & 3 & $6 \%$ \\
Total & 45 & $100 \%$ \\
\hline
\end{tabular}

Validity Test Results The first test is carried out to test the advertising exposure and buying interest variables. This validity test used the Pearson Moment formula. This test was carried out on 45 respondents and processed using SPPS v21, so that the r-table value is obtained, namely 0.294. The results of the validity test for variable $\mathrm{X}$ are as follows:

\begin{tabular}{|c|c|c|c|}
\hline \multicolumn{4}{|c|}{ Correlations } \\
\hline & & Total_X1 & formation \\
\hline \multirow{3}{*}{$\mathrm{X} 1$} & Pearson Correlation & $.647^{* *}$ & \multirow{3}{*}{ Valid } \\
\hline & Sig. (2-tailed) & ,000 & \\
\hline & $\mathrm{N}$ & 45 & \\
\hline \multirow{3}{*}{$\mathrm{X} 2$} & Pearson Correlation & $.735^{* *}$ & \multirow{3}{*}{ Valid } \\
\hline & Sig. (2-tailed) &, 000 & \\
\hline & $\mathrm{N}$ & 45 & \\
\hline \multirow{3}{*}{ X3 } & Pearson Correlation & $.677^{* *}$ & \multirow{3}{*}{ Valid } \\
\hline & Sig. (2-tailed) & 0,000 & \\
\hline & $\mathrm{N}$ & 45 & \\
\hline \multirow{3}{*}{ X4 } & Pearson Correlation & $.709^{* *}$ & \multirow{3}{*}{ Valid } \\
\hline & Sig. (2-tailed) &, 000 & \\
\hline & $\mathrm{N}$ & 45 & \\
\hline \multirow{3}{*}{$\mathrm{X} 5$} & Pearson Correlation & $.693^{* *}$ & \multirow{3}{*}{ Valid } \\
\hline & Sig. (2-tailed) & ,000 & \\
\hline & $\mathrm{N}$ & 45 & \\
\hline \multirow{3}{*}{ X6 } & Pearson Correlation & $.606^{* *}$ & \multirow{3}{*}{ Valid } \\
\hline & Sig. (2-tailed) & 000 & \\
\hline & $\mathrm{N}$ & 45 & \\
\hline \multirow{3}{*}{$\mathrm{X} 7$} & Pearson Correlation & $.848^{* *}$ & \multirow{3}{*}{ Valid } \\
\hline & Sig. (2-tailed) &, 000 & \\
\hline & $\mathrm{N}$ & 45 & \\
\hline \multirow{3}{*}{$\mathrm{X} 8$} & Pearson Correlation & $.859^{* *}$ & \multirow{3}{*}{ Valid } \\
\hline & Sig. (2-tailed) &, 000 & \\
\hline & $\mathrm{N}$ & 45 & \\
\hline
\end{tabular}

Table 3. Results of the Validity Test of Variable X

Source: Data processed with SPSS 21

Based on table 3, through the respondent's data which was carried out to 45 people and processed using SPSS v21, it resulted that all the items tested had a calculated r-value greater than $r$ table, namely 0.294 . So it can be concluded that all items of the questionnaire statement for variable $\mathrm{X}$, namely ad exposure are declared valid.

Table 4. Variable Validity Test Results Y

\begin{tabular}{llll}
\hline \multicolumn{2}{l}{ Correlations } & Total_Y & Information \\
\cline { 3 - 4 } Y1 & Pearson Correlation & $.580^{* *}$ & \\
\cline { 2 - 3 } & Sig. (2-tailed) &, 000 & Valid \\
\hline
\end{tabular}




\begin{tabular}{|c|c|c|c|}
\hline & $\mathrm{N}$ & 45 & \\
\hline & Pearson Correlation & $.783^{* *}$ & \\
\hline \multirow[t]{3}{*}{ Y2 } & Sig. (2-tailed) & ,000 & Valid \\
\hline & $\mathrm{N}$ & 45 & \\
\hline & Pearson Correlation & $.798^{* *}$ & \\
\hline \multirow[t]{3}{*}{ Y3 } & Sig. (2-tailed) &, 000 & Valid \\
\hline & $\mathrm{N}$ & 45 & \\
\hline & Pearson Correlation & $.904^{* *}$ & \\
\hline \multirow[t]{3}{*}{ Y4 } & Sig. (2-tailed) &, 000 & Valid \\
\hline & $\mathrm{N}$ & 45 & \\
\hline & Pearson Correlation & $.761^{* *}$ & \\
\hline \multirow[t]{3}{*}{ Y5 } & Sig. (2-tailed) &, 000 & Valid \\
\hline & $\mathrm{N}$ & 45 & \\
\hline & Pearson Correlation & $.663^{* *}$ & \\
\hline \multirow[t]{3}{*}{ Y6 } & Sig. (2-tailed) & ,000 & Valid \\
\hline & $\mathrm{N}$ & 45 & \\
\hline & Pearson Correlation & $.770^{* *}$ & \\
\hline \multirow[t]{3}{*}{ Y7 } & Sig. (2-tailed) &, 000 & Valid \\
\hline & $\mathrm{N}$ & 45 & \\
\hline & Pearson Correlation & $.909^{* *}$ & \\
\hline \multirow[t]{2}{*}{ Y8 } & Sig. (2-tailed) & ,000 & Valid \\
\hline & $\mathrm{N}$ & 45 & \\
\hline \multirow[t]{3}{*}{ Y9 } & Pearson Correlation & $.692^{* *}$ & Valid \\
\hline & Sig. (2-tailed) &, 000 & \\
\hline & $\mathrm{N}$ & 45 & \\
\hline \multirow[t]{3}{*}{ Y10 } & Pearson Correlation & $.776^{* *}$ & Valid \\
\hline & Sig. (2-tailed) &, 000 & \\
\hline & $\mathrm{N}$ & 45 & \\
\hline \multirow[t]{3}{*}{ Y11 } & Pearson Correlation & $.711^{* *}$ & Valid \\
\hline & Sig. (2-tailed) &, 000 & \\
\hline & $\mathrm{N}$ & 45 & \\
\hline \multirow[t]{4}{*}{ Y12 } & Pearson Correlation & $.673^{* *}$ & Valid \\
\hline & Sig. (2-tailed) &, 000 & \\
\hline & $\mathrm{N}$ & 45 & \\
\hline & Pearson Correlation & $.864^{* *}$ & Valid \\
\hline \multirow[t]{2}{*}{ Y13 } & Sig. (2-tailed) &, 000 & \\
\hline & $\mathrm{N}$ & 45 & \\
\hline \multirow[t]{3}{*}{ Y14 } & Pearson Correlation & $.362^{*}$ & Valid \\
\hline & Sig. (2-tailed) &, 014 & \\
\hline & $\mathrm{N}$ & 45 & \\
\hline \multirow[t]{3}{*}{ Y15 } & Pearson Correlation & $.828 * *$ & Valid \\
\hline & Sig. (2-tailed) & ,000 & \\
\hline & $\mathrm{N}$ & 45 & \\
\hline
\end{tabular}

Source: Data processed with SPSS 21

Based on table 4, shows that all the items of the respondents' statements that have been processed using SPSS v21 have a count value greater than $r$ table 0.294 . So that referring to these results, it can be concluded that all statement items for variable $\mathrm{Y}$, namely Purchase Intention, can be declared valid.

Reliability test is carried out on statement items given to respondents who have been declared valid and tested using the Cronbach's Alpha method. The criteria for a variable to be declared reliable is greater than 0.600 . Reliable less than 0.600 is less reliable and the results on this reliability test processed using SPSS v21 are as follows:

Table 5. Reliability Test Results of Variable X Advertising Exp

\begin{tabular}{cc}
\hline \multicolumn{2}{c}{ Reliability Statistics } \\
\hline Cronbach's Alpha & N of Items \\
\hline ,936 & 15 \\
\hline
\end{tabular}

Source: Data processed with SPSS 21

Table 6. Reliability Test Results of Variable Y Purchase Interest

\begin{tabular}{cc}
\hline \multicolumn{2}{c}{ Reliability Statistics } \\
\hline Cronbach's Alpha & N of Items \\
\hline, 937 & 15
\end{tabular}

Source: Data processed with SPSS 21

Based on the table above, the value in Cronbach's Alpha on the reliability test of the statement on variable $\mathrm{X}$ of advertising exposure is 0.936 and variable $\mathrm{Y}$ is buying interest 0.937 . It can be concluded that the two variables are declared reliable because they exceed Cronbach's Alpha value and can be used for research using statistical analysis at a later stage.

\section{Statistical Test Results}

This correlation analysis test was conducted to test how strong the relationship between variable $\mathrm{X}$ (Advertising exposure) and variable Y (Purchase Intention) was. Processing of this 
correlation test was carried out using SPSS v21 using the Pearson Product Moment formula. Based on the test results, there is a significant relationship between advertisement exposure variables and purchase interest in Shopee's version of Shopee 4.4 Mega Electronic Sale: New Refrigerator, 50\% lower price with a correlation value obtained of 0.663 based on the table below, the relationship between advertisement exposure variables and buying interest is significant or strong enough.

Table 7. Model Summary

\begin{tabular}{|c|c|c|c|c|}
\hline \multicolumn{5}{|c|}{ Model Summary } \\
\hline Model & $\mathrm{R}$ & $\begin{array}{c}\mathrm{R} \\
\text { Square }\end{array}$ & $\begin{array}{l}\text { Adjusted R } \\
\text { Square }\end{array}$ & $\begin{array}{c}\text { Std. Error of the } \\
\text { Estimate }\end{array}$ \\
\hline 1 & $.663 a$ &, 440 &, 427 & 6,086 \\
\hline \multicolumn{5}{|c|}{ a. Predictors: (Constant), Advertising } \\
\hline
\end{tabular}

Table 8. Coefficients t-test analysis results in a

\begin{tabular}{|c|c|c|c|c|c|}
\hline \multirow{2}{*}{ Model } & \multicolumn{2}{|c|}{$\begin{array}{l}\text { Unstandardized } \\
\text { Coefficients } \\
\end{array}$} & \multirow{2}{*}{$\begin{array}{l}\text { Standardized } \\
\text { Coefficients } \\
\text { Beta }\end{array}$} & \multirow[b]{2}{*}{$\mathrm{t}$} & \multirow[b]{2}{*}{ Sig. } \\
\hline & $\mathrm{B}$ & $\begin{array}{l}\text { Std. } \\
\text { Error }\end{array}$ & & & \\
\hline 1 (Constant) & 16,911 & 6,632 & & 2,550 &, 014 \\
\hline ADVERTISING & 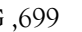 &, 120 & ,663 & 5,814 &, 000 \\
\hline
\end{tabular}

a. Dependent Variable: BUY INTEREST

Source: processed research data, 2021

The analysis of the coefficient of determination was carried out to measure the effectiveness of the exposure to Shopee's advertisement version of Shopee 4.4 Mega Electronic Sale: New Refrigerator, Banting, $50 \%$ price on student and female student buying interest can be seen from the $\mathrm{R}$ square column in the table above or also known as the coefficient of determination. Therefore, it can be concluded that $44 \%$ of buying interest in electronic products is influenced by the effectiveness of exposure to Shopee's advertising version of Shopee 4.4 Mega Electronics Sale: New Refrigerators, 50\% lower prices, and $60 \%$ are influenced by other factors that can affect purchase interest which was not examined by researchers.

The t-test in Table 8 is to determine the significance of the effectiveness of the independent variable (advertisement exposure) on the dependent variable, namely buying interest individually or partially. Based on the results of the correlation in Table 39, the significance value obtained is 0.000 , so it can be interpreted that the probability value is below 0.05 and $t$ count 5.814 is greater than $t$ table 1.681, it can be concluded that $\mathrm{Ha}$ is accepted, meaning that there is an influence of exposure to Shopee Youtube advertisement version of Shopee 4.4 Mega Elektronik Sale: New Refrigerator Reduces $50 \%$ price on student buying interest.

In this section, it is to explain whether there is a significant (significant) influence of the advertising exposure variable $(\mathrm{X})$ on purchase intention (Y).

Table 9. ANOVA

\begin{tabular}{lccccc}
\hline Model & $\begin{array}{c}\text { Sum of } \\
\text { Squares }\end{array}$ & df & $\begin{array}{c}\text { Mean } \\
\text { Square }\end{array}$ & F & Sig. \\
\hline 1 Regression & 1251,977 & 1 & 1251,977 & $33,806.000 \mathrm{~b}$ \\
Residual & 1592,467 & 43 & 37,034 & \\
Total & 2844,444 & 44 & & \\
\hline a.Dependent Variable: BUYING INTEREST & \\
b.Predictors: (Constant), ADVERTISING & \\
Source: processed research data, 2021
\end{tabular}

Based on the results of the output, it can be seen that $\mathrm{F}$ count $=33,806$ with a probability significance level of $0.000<0.005$ so that the regression model can be used to predict the purchase interest variable. 
Table 10. Simple Linear Regression Analysis Test Results Coefficients a

\begin{tabular}{|c|c|c|c|c|c|}
\hline \multirow{3}{*}{ Model } & \multirow{2}{*}{\multicolumn{2}{|c|}{$\begin{array}{l}\text { Unstandardized } \\
\text { Coefficients }\end{array}$}} & \multirow{3}{*}{$\begin{array}{l}\text { Standardized } \\
\text { Coefficients } \\
\text { Beta }\end{array}$} & \multirow{3}{*}{$\mathrm{t}$} & \multirow{3}{*}{ Sig. } \\
\hline & & & & & \\
\hline & B & $\begin{array}{l}\text { Std. } \\
\text { Error }\end{array}$ & & & \\
\hline 1 (Constant) & 16,91 & 16,632 & & 2,550 & 014 \\
\hline ADVERTISING & 699 &, 120 & ,663 & 5,814 & 4,000 \\
\hline
\end{tabular}

a. Dependent Variable: BUY INTEREST

Source: processed research data, 2021

Based on the coefficients table, in column B the constant number of unstandardized coefficients (a) is 16,911 , while the $\mathrm{X}$ value or advertising exposure (b) is 0.699 , so the equation in the regression can be written as follows:

$$
\begin{gathered}
Y=a+B x \\
Y=16,911+0.699
\end{gathered}
$$

The coefficient $b$ is called the regression direction coefficient and represents the average change in the $\mathrm{Y}$ variable for each change in variable $\mathrm{X}$ by units. This change is an increase in $b$ is positive and a decrease in $b$ is negative. So that the equation can be translated as follows: (1) A constant of 16,911 states that if there is no $\mathrm{Y}$ variable, the participation value is 16,911 . (2) The $\mathrm{X}$ regression coefficient of 0.699 states that for each additional 1 value of advertising exposure, the value of purchase interest will increase by 0.699 . Conversely, if there is a reduction of 1 in the value of ad exposure, then the value of buying interest will decrease by 0.699 .

\section{Discussion}

The results showed that the characteristics of respondents related to gender and age were dominated by women with a percentage of $76 \%$ and those from $19-24$ years old with a percentage of $67 \%$. This is in line with Fauziah's (2020) research that Shopee ecommerce users are dominated by young women. The results of the Snapcart Survey conducted in January 2018 show that women dominate the role of online shopping consumers by $65 \%$ (BPS, 2020). Shopee's market tag is women, which in this case are easily influenced by advertising promos that offer high discounts. Shopee comes with an attractive promo tagline so that it is effective in attracting consumers.

The results of the study answered the research objectives presented at the beginning regarding the influence of Shopee Ads in Shopee Version 4.4 Mega Electronics Sale: New Fridge 50\% discount on Youtube on student buying interest. This research proves that the Shopee ad version of Shopee 4.4 Mega Elektronik Sale: New Fridge 50\% discount on Youtube has a positive and significant effect on student buying interest with a significance value of 0.00 . The direction of a positive relationship between advertising variables and buying interest indicates that any increase in the intensity of advertising on Youtube media can attract consumers more and influence their perception of selfactualization by making purchases. The results of this study support several previous literature studies such as the research of Wijaya \& Siahaan (2020) which states that Youtube Ads and buying interest among students towards electronic products have a positive and significant correlation. Research by Inkiriwang et al (2021) also shows results which state that Youtube advertising has a positive and significant effect on buying interest. This is because Youtube ads get a lot of attention from students and create a positive impression. The information obtained from 
these advertisements motivates individuals to carry out product purchase activities (action).

The results showed that $44 \%$ of the buying interest in electronic products was influenced by the effectiveness of exposure to Shopee's advertisement version of Shopee 4.4. Mega Elektronik Sale: New Refrigerator with 50\% Price. This shows that advertisements with discount promo content, discounts, and other advantages for consumers will have a considerable influence in shaping buying interest and decisions. Dewi \& Hartono (2019) explain that a marketing strategy is needed to attract the public to the products offered, while e-commerce has affordable prices, promos or discounts, product diversification, free shipping rates, fast delivery, and other conveniences that can affect interest. consumer.

The results of this study also prove that students' interest in electronic goods is quite high. Several questions that were asked related to the respondent's interest in buying electronic promo products at Shopee after seeing Youtube advertisements were answered by the majority of respondents in the agreed category. This is in line with the idea that students are currently a digital generation who are proficient and infatuated with the latest technology that provides easy and fast access so that discounts or promos related to electronic goods or other objects related to technology will get enough attention (Hadion Wijoyo et al., 2020: 28). This is also in line with the AISAS concept which states that the last stage of the promotion process is no longer the consumer's action in using the product (action) but sharing experiences ( $\mathrm{Hu}$ \& Qiao, 2018). The concept of sharing is also one of the characteristics of generation $\mathrm{Z}$ in advertising in the modern era.

\section{Conclusion}

The student's need for digitalized products encourages the consumption of various modern technological devices. Students who are still in the late teens to early adulthood category tend to be easily influenced by product promos that provide more discounts. Shopee advertisement Shopee version 4.4 Mega Electronic Sale on the youtube page is very close to the daily lives of students. The more frequently students access Youtube, the more often the ad content influences student perceptions which can form an impetus for them to buy the product. This is evidenced by the results of the study that $44 \%$ of students' buying interest was influenced by Shopee advertisement Shopee Version 4.4 Mega Elektronik Sale. This means that the more intense the advertisement is shown, the more likely it is to strengthen students' buying interest in the electronic products offered. The Shopee Version 4.4 Mega Elektronik Sale version of Shopee advertisement is oriented to the AISAS advertising concept (attention, interest, search, action, and sharing). Technological developments have made the ultimate goal of advertising content shift from user action to sharing between users. The results of the research prove that Youtube Ads or Youtube Ads can attract students' interest. Interest is the second component in the AISAS concept so that interest is said to be part of the purchase planning process which contributes greatly to consumer decision making. The direction of the relationship between Shopee's Shopee 4.4 Mega Electronic Sale version on the Youtube page and student buying interest is a significant positive, which 
means an increase in advertising intensity will be followed by an increase in student buying interest

\section{Recommendations}

Subsequent research can use a larger and wider sample, especially not only referring to students but also the general public, as well as being compared to other online shops.

\section{References}

APJII. (2020). Buletin APJII. In Asosiasi Penyelenggara Jasa Internet Indonesia (p. 1). https://apjii.or.id/content/read/104/50 3/BULETIN-APJII-EDISI-74---November2020

Arnianti, H., Khoirunnisa, G., M, H. A., Geulis, \& Herlina. (2019). Pengaruh Iklan Youtube Terhadap Minat Beli Vivo Smartphone ( Survei Pada Mahasiswa Universitas Singaperbangsa Karawang Jurusan Manajemen Angkatan 2016, 2017 Dan 2018 ) Keywords: YouTube Ads, purchase interest atau perusahaan . Cara beriklan sangat berp. Cakrawala Management Business Journal, 2(1), 172184.

BPS (Badan Pusat Statistik). (2020). Statistik ECommerce 2020.

Daryanto, W. M., Meiliawati, P. T., \& Syarafina, T. (2020). The Financial Impact of Conventional Retail Industry Due To Online Based Shopping Model In Indonesia (Case Study of PT Matahari Department Store Tbk And PT Shopee International Indonesia Period Of 2013. 2018). South East Asia Journal of Contemporary Business, Economics and Law,
21(2), 26-37.

Dewi, R. M., \& Hartono, T. (2019). ECommerce Marketing Communication Strategies on Consumer Buying Interest. IOP Conference Series: Materials Science and Engineering, 662(3). https://doi.org/10.1088/1757-

899X/662/3/032013

Duffett, R., Edu, T., \& Negricea, C. I. (2020). Effect of Youtube Advertising on Intention-To-Purchase and Purchase among Generation $\mathrm{Y}$ in a Developing African and European Country. Transformations in Business $\mathbb{E}$ Economics, 19(March), 112-132.

Dyego, A., \& Oktavianti, R. (2020). The Impact of Electronic Word-of-Mouth on the Purchase Intention. Advances in Social Science, Education and Humanities Research, 478(Ticash), 410-415. https://doi.org/10.2991/assehr.k.20120 9.063

Emzir. (2011). Metode penelitian Pendidikan Kuantitati dan Kualitatif. Rajawali Pers.

Fauziah. (2020). Strategi Komunikasi Bisnis Online Shop "Shoppe" Dalam Meningkatkan Penjualan. Jurnal Abiwara, Vol. 1, No(ISSN 2686-1577), hal. 45-53. http://ojs.stiami.ac.id/index.php/ABIW ARA/article/view/792

Ferdinand, A. (2014). Metode Penelitian Manajemen. Penerbit Universitas Diponegoro.

Foster, B., \& Johansyah, M. D. (2019). The effect of product quality and price on buying interest with risk as intervening variables (study on Lazada.com site users). International Journal of Innovation, Creativity and Change, 9(12), 66-78. 
Hadion Wijoyo, Indrawan, I., Cahyono, Y., Handoko, A. L., \& Santamoko, R. (2020). Generasi Z Eु Revolusi Industri 4.0 Penulis (Issue July). CV Pena Persada. https://www.researchgate.net/publicatio n/343416519_GENERASI_Z_REVOL USI_INDUSTRI_40

Hansen, S. S., Lee, J. K., \& Lee, S. Y. (2014). Consumer-generated ads on Youtube: Impacts of source credibility and need for cognition on attitudes, interactive behaviors, and eWOM. Journal of Electronic Commerce Research, 15(3), 254266.

Hayani, I. M. N., \& Wulandari, P. Y. (2017). Perbedaan Kecenderungan Perilaku Agresi Ditinjau Dari Harga Diri Pada Mahasiswa. Jurnal Psikologi Pendidikan Dan Perkembangan, 06, 32-34. Father?s involvement in parenting can affect many aspect in adolescent, including emotion. The survey that was conducted by the writer showed that adolescent in Surabaya, in those case were students of SMKN 6 Surabaya, in general have a moderate emotional

Hu, Z., \& Qiao, J. (2018). Research on We Chat Matrix Marketing Process of Ecommerce Enterprises Based on AISAS Model. International Conference on Arts and Design, Education and Social Sciences (ADESS), 878-884. https://doi.org/10.12783/dtssehs/adess 2017/17883

Inkiriwang, N. A., Tumbuan, illem J. . A., \& Tumewu, F. J. (2021). Analyzing Of Youtube's Advertising On Consumer Buying Interest (Study Case: Students Of Sam Ratulangi University). Jurnal EMBA,
9(1), 236-245.

Juliandi, A. (2013). Metodelogi Penelitian Kuantitatif: untuk ilmu-ilmu. M2000.

Kamila, H. N., \& Usman, O. (2021). Effect of Promotion, Ease of Use \&amp; Consumer Confidence on Online Purchasing Decisions at Shopee. SSRN Electronic Journal, 1-21. https://doi.org/10.2139/ssrn.3768103

Kompas. (2020). Ini 10 Iklan YouTube Terpopuler Periode Januari-Juni 2020. https://money.kompas.com/read/2020/ 07/19/200000626/ini-10-iklan-youtubeterpopuler-periode-januari-juni-2020

Layla, S. L., \& Usman, O. (2019). Effect of Advertising, Word of Mouth, Website Quality, and Risk Perception on Buying Interest (Study on Consumer ECommerce Shopee). SSRN Electronic Journal.

https://doi.org/10.2139/ssrn.3311368

Manzilati, A. (2017). Metode Penelitian Kualitatif: Paradigma, Metode, dan Aplikasi. UB Press.

Morisaan. (2010). Periklanan: Komunikasi Pemasaran Terpadu. Pranadamedia Group.

Orinaldi, M. (2021). Dampak Iklan Shopee Versi Shopee 12 . 12 Birthday Sale Di Laman Youtube pada Minat Beli Masyarakat. Ekonomis: Journal of Economics and Business, 5(1), 226-239. https://doi.org/10.33087/ekonomis.v5i 1.315

Oxford Business Group. (2020). E-commerce opportunities in Indonesia's retail market. https://oxfordbusinessgroup.com/overvi 
ew/delivered-success-market-dominatedbrick-and-mortar-stores-e-commerceproving-attractive-young-tech

Rubiati, \& Heriyana. (2020). Pengaruh Gaya Hidup dan Kemudahan Terhadap Minat Beli Mahasiswa dalam Berbelanja Online. Jurnal Aplikasi Manajemen Dan Bisnis, 1(1), 57-65.

Siyoto, S., \& Sodik, A. (2015). Dasar Metodologi Penelitian. Literasi Media Publishing.

Statista. (2020). Total e-commerce revenue in Tiger Cub economies from 2017 to 2020 with a forecast until 2024. https://www.statista.com/forecasts/1117 690/southeast-asia-e-commerce-revenuein-tiger-cub-states

Statista. (2021a). Percentage of U.S. internet users who use YouTube as of 3rd quarter 2020, by age group. https://www.statista.com/statistics/2962 27/us-youtube-reach-age-gender/

Statista. (2021b). Top 10 e-commerce sites in Indonesia as of 4th quarter 2020, by monthly traffic.

https://www.statista.com/statistics/8697 00/indonesia-top-10-e-commerce-sites/

Sugiyono. (2013). Metode Penelitian Kuantitatif Kualitatif dan REBD. Alfabeta.

Suhandang, K. (2016). Manajemen, Kiat, dan Startegi Periklanan. Nuansa Cendekia.

Taruli, A. E., Chan, A., \& Tresna, P. W. (2020). The Effect Of Gamification " Shopee Tanam " Version On The Customer Engagement Of Shopee Indonesia Mobile Application ( Survey Of Shopee In App Games Users' S In Bandung City ). Jurnal Pemikiran Dan
Penelitian Administrasi Bisnis Dan Kewirausahaan, 5(3), 283-295. https://doi.org/10.24198/adbispreneur. v5i3.30265

Warta Ekonomi. (2018). Iklan Shopee Ini Terpopuler Versi YouTube Indonesia. https://www.wartaekonomi.co.id/read1 80609/iklan-shopee-ini-terpopuler-versiyoutube-indonesia

Wijaya, H., \& Siahaan, A. L. D. (2020). Iklan oppo F9 "Vooc Flash-Charge" dan Minat Membeli Produk (Studi Korelasional Tentang Terpaan Iklan Oppo F9 "VOOC Flash-Charge" pada YouTube Ads Terhadap Minat Membeli Produk di Kalangan Mahasiswa Universitas Sumatera Utara). Komunika, 14(2), 60 70. 
Journal of Digital Marketing And Halal Industry

Vol. 3, No. 1 (2021) 49-62

http://journal.walisongo.ac.id/index.php/JDMHI/index DOI: http://dx.doi.org/10.21580/jdmhi.2021.3.1.7442

$62 \mid \mathrm{P}$ a g e 